\title{
Acid Extrusion Is Induced by Osteoclast Attachment to Bone Inhibition by Alendronate and Calcitonin
}

\author{
Zoran Zimolo, Gregg Wesolowski, and Gideon A. Rodan \\ Department of Bone Biology and Osteoporosis Research, Merck Research Laboratories, West Point, Pennsylvania 19486
}

\begin{abstract}
Acid extrusion is essential for osteoclast (OC) activity. We examined $\mathrm{Na}^{+}$and $\mathrm{HCO}_{3}{ }^{-}$-independent $\mathrm{H}^{+}$extrusion in ratand mouse $\mathrm{OCs}$ by measuring intracellular $\mathrm{pH}\left(\mathrm{pH}_{\mathrm{i}}\right)$ changes, with the $\mathrm{pH}_{\mathrm{i}}$ indicator $\mathrm{BCECF}$ (biscarboxyethyl5-(6) carboxyfluorescein) after $\mathrm{H}^{+}$loading with an ammonium pulse. $90 \%$ of $\mathrm{OCs}$ attached to glass do not possess $\mathrm{HCO}_{3}{ }^{-}$and $\mathrm{Na}^{+}$-independent $\mathrm{H}^{+}$-extrusion (rate of $\mathrm{pH}_{\mathrm{i}}$ recovery $=0.043 \pm 0.007(\mathrm{SEM}) \mathrm{pH} \mathrm{U} / \mathrm{min}, n=26)$. In contrast, in OCs attached to bone, the $\mathrm{pH}_{\mathrm{i}}$ recovery rate is $0.228 \pm 0.011 \mathrm{pH}_{\mathrm{i}} \mathrm{U} / \mathrm{min}, n=25$. OCs on bone also possess a $\mathrm{NH}_{4}{ }^{+}$-permeable pathway not seen on glass. The boneinduced $\mathrm{H}^{+}$extrusion was inhibited by salmon calcitonin $\left(10^{-8} \mathrm{M}\right.$, for $\left.2 \mathrm{~h}\right)$, and was not present after pretreating the bone slices with the aminobisphosphonate alendronate (ALN). At ALN levels of $0.22 \mathrm{nmol} / \mathrm{mm}^{2}$ bone, $\mathrm{H}^{+}$extrusion was virtually absent $12 \mathrm{~h}$ after cell seeding $(0.004 \pm 0.002 \mathrm{pH}$ $\mathrm{U} / \mathrm{min}$ ) and $\sim 50 \%$ inhibition was observed at $0.022 \mathrm{pmol}$ ALN/mm ${ }^{2}$ bone. The $\mathrm{Na}^{+}$-independent $\mathrm{H}^{+}$extrusion was not inhibited by bafilomycin $A_{1}$ (up to $10^{-7} \mathrm{M}$ ), although a bafilomycin $A_{1}\left(10^{-8} \mathrm{M}\right)$-sensitive $\mathrm{H}^{+}$pump was present in membrane vesicles isolated from these osteoclasts. These findings indicate that $\mathrm{Na}^{+}$-independent acid extrusion is stimulated by osteoclast attachment to bone and is virtually absent when bone is preincubated with ALN, or when osteoclasts are treated with salmon calcitonin. (J. Clin. Invest. 1995. 96:2277-2283.) Key words: bone resorption $\cdot \mathrm{H}^{+}$ATPase $\bullet$ intracellular $\mathbf{p H} \cdot$ bafilomycin $\cdot$ bisphosphonate
\end{abstract}

\section{Introduction}

Osteoclasts $(\mathrm{OC})^{1}$ alternate between resorptive and motile phases (1). The resorptive phase requires attachment to mineralized matrix and formation of a clear zone that separates the

Portions of this work were presented in abstract form (1992. J. Bone Miner. Res. 7(S1):S311 and 1994. J. Bone Miner. Res. 9(S1):S201, S248).

Address correspondence to Gidean A. Rodan, Department of Bone Biology and Osteoporosis Research, Merck Research Laboratories, West Point, PA 19486. Phone:215-652-7478; FAX:215-652-4328.

Received for publication 21 March 1995 and accepted in revised form 27 July 1995

1. Abbreviations used in this paper: ALN, alendronate; BCECF, biscarboxyethyl-5-(6) carboxyfluorescein; $\mathrm{OC}$, osteoclasts; $\mathrm{pH}_{\mathrm{i}}$, intracellular $\mathrm{pH}$; TMACl, tetramethylammonium chloride; TRAP, tartrate-resistant acid phosphatase.

J. Clin. Invest.

(C) The American Society for Clinical Investigation, Inc.

0021-9738/95/11/2277/07 \$2.00

Volume 96, November 1995, 2277-2283 basolateral from the ruffled membrane. Osteoclasts rendered inactive by bisphosphonates $(2,3)$ or calcitonin $(4,5)$, as well as by the absence of c-src (6) lack ruffled membrane. During bone resorption, osteoclasts secrete $\mathrm{H}^{+}$into a resorption lacuna via a $\mathrm{Na}^{+}$-independent vacuolar( $\mathrm{V}$ )-type proton pump (7-11). The V-ATPases are very sensitive to the macrolide antibiotic bafilomycin $\mathrm{A}_{1}\left(\mathrm{IC}_{50} \approx 1 \mathrm{nM}[12]\right)$ shown to bind to the hydrophobic, $17-\mathrm{kD} \mathrm{H}^{+}$channel subunit $(13,14)$. Although (V)$\mathrm{H}^{+}$pumps are highly conserved (15), the $\mathrm{H}^{+}$-pumps in osteoclasts and osteoclastoma cells may have some unique characteristics $(16,17)$. The aminobisphosphonate alendronate (4amino-1-hydroxybutylidene bisphosphonate $[\mathrm{ALN}])$ is a potent inhibitor of osteoclastic bone resorption in vitro and in vivo (3, 18 ). The effects of bisphosphonates on bone have been known for over $20 \mathrm{yr}$ (19), but their mode of action is still uncertain. More than one mechanism may be involved and several have been proposed: interference with osteoclastic differentiation (20-24), toxicity to osteoclasts $(25,26)$, and metabolic inhibition (27). ALN has an amphipatic structure and a high avidity for hydroxyapatite. It concentrates at sites of bone resorption and should be locally released within the resorption space, due to the acidification produced by osteoclasts (3). However, osteoblasts may also be the target cells for bisphosphonate action (28), and in turn affect osteoclast activity. The object of this study on single osteoclasts was to obtain direct physiologic evidence for acid extrusion and to examine the effects of ALN on this process.

We observed that osteoclasts plated on bone acquire the capacity for $\mathrm{Na}^{+}$-independent $\mathrm{H}^{+}$extrusion. This property was inhibited in a dose-dependent manner by preincubating the bone with alendronate or by addition of salmon calcitonin to the culture media. This is a direct demonstration of a quantifiable pharmacological effect of a bisphosphonate on single osteoclasts which should enable future study of the bisphosphonate mechanism of action.

\section{Methods}

Materials. Chemicals were obtained from Sigma Chemical Co. (St. Louis, MO), or Fluka Chemical Corp. (Ronkonkoma, NY) and were of the finest grade available. Bovine collagen type I was from Collagen Corp. (Palo Alto, CA), salmon calcitonin was from Bachem California (Torrance, CA). BCECF/AM and $\mathrm{H}_{2}$ DIDS were from Molecular Probes, Inc. (Eugene, OR), valinomycin from Calbiochem Corp. (San Diego, CA), acridine orange from International Biotechnology Laboratories, Inc. (New Haven, CT). Collagenase was from Wako Bioproducts, Inc. (Richmond, VA) and dispase from Boehringer Mannheim (Mannheim, Germany). Bafilomycin $A_{1}$, etidronate, and alendronate were from Merck \& Co., Inc. (Rahway, NJ) chemical supplies.

Cells and cell culture. Rat osteoclasts were isolated from the humeri and femora of 1-5-d-old Sprague-Dawley rats, being held without food the night before the experiment. The periosteum and cartilage were removed, the bones were split longitudinally, and the cells were scraped from the bone marrow cavity side, using a low magnification microscope. This procedure was carried out in 199 medium (GIBCO, Gaith- 
ersburg, MD), containing $12 \mathrm{mM}$ bicarbonate, $100 \mathrm{U} / \mathrm{ml}$ penicillin $\mathrm{G}$, $100 \mathrm{mg} / \mathrm{ml}$ streptomycin sulphate, and $20 \mathrm{mM}$ Hepes/Tris, $\mathrm{pH}=7.1$. The cells were plated either on flame sterilized glass coverslips or on bone slices glued to coverslips, incubated for $1 \mathrm{~h}$ at $37^{\circ} \mathrm{C} / 5 \% \mathrm{CO}_{2}$ in the above medium containing $10 \%$ FBS JRH Biosciences, Lenexa, KS. Unless stated otherwise, the experiments were performed $12 \mathrm{~h}$ after cell attachment.

Mouse osteoclast-like cells were generated in vitro by coculturing $2.4 \times 10^{6}$ mouse neonatal calvaria-derived osteoblastic cells with 1.2 $\times 10^{7}$ mouse bone marrow cells on collagen gels for $7 \mathrm{~d}$ in the presence of $10 \mathrm{nM}$ 1,25-dihydroxyvitamin D3 (in a MEM [GIBCO] supplemented with $10 \%$ FBS, $100 \mathrm{U} / \mathrm{ml}$ penicillin $\mathrm{G}$ and $100 \mathrm{mg} / \mathrm{ml}$ streptomycin sulphate in $10 \mathrm{~cm}$ plastic dishes). Between 4 and $7 \mathrm{~d}$ of coculture, cells fuse to form multinucleated cells that exhibit osteoclastic features including calcitonin receptors, tartrate resistant acid phosphatase (TRAP), $\alpha_{v} \beta_{3}$ integrins and the formation of pits on bone slices (29, 30 ). Cells were released from collagen by $0.1 \%$ collagenase; $0.1 \%$ dispase treatment $\left(15 \mathrm{~min}, 37^{\circ} \mathrm{C}, 5 \% \mathrm{CO}_{2}\right)$. The multinucleated cells were larger and positive for TRAP. After their release, cells were cultured either on glass or on bone slices, as mentioned above.

Intracellular $\mathrm{pH}$ measurements. After cultivation, the cells were loaded with a $\mathrm{H}^{+}$-sensitive fluorescent dye BCECF (biscarboxyethyl5-(6) carboxyfluorescein; $5 \mathrm{mM}$ ) for $60 \mathrm{~min}$ at room temperature, conditions which minimize vesicular accumulation of the dye. Loaded cells were placed in a sealed, perfused $(1 \mathrm{ml} / \mathrm{min})$ microscope chamber (volume $\approx 100 \mu \mathrm{l}$ ), heated to $37^{\circ} \mathrm{C}$. Fluorescence intensity in single cells was measured by adjusting the diaphragm in front of the photomultiplier tube. The cells were sequentially illuminated with two excitation wavelengths ( $\lambda_{e x}=495$ and $440 \mathrm{~nm}$ ) using two monochromators. The ratio of the emission intensities $\left(\lambda_{e m}=520-560 \mathrm{~nm}\right)$ was calculated using the software of PTI (Photon Technology International, New Brunswick, $\mathrm{NJ}$ ) and readings were collected at 0.5-s intervals. Background correction was performed for each experiment. Conversion of BCECF fluorescence ratio to $\mathrm{pH}$ units was done by calibration with nigericin (31). The standard $\mathrm{NaCl}$ (or tetramethylammonium chloride [TMACl]) solution contained (mM): $130 \mathrm{NaCl}$ (TMACl), $4 \mathrm{KCl}, 1$ $\mathrm{MgSO}_{4}, 1.7 \mathrm{CaCl}_{2}, 1 \mathrm{NaH}_{2} \mathrm{PO}_{4}, 10$ glucose, 20 Hepes/Tris; $\mathrm{pH}=7.4$. $\mathrm{NH}_{4} \mathrm{Cl}$ solution contained $20 \mathrm{mM} \mathrm{NH}_{4} \mathrm{Cl}$ and $110 \mathrm{mM}$ (TMACl), which replaced $\mathrm{NaCl}$. In $\mathrm{Na}^{+}$-free solutions, tetramethylammonium phosphate was added instead of sodium phosphate. Tetramethylammonium phosphate was prepared by titration of tetramethylammonium hydroxide with phosphoric acid. $\mathrm{H}^{+}$and $\mathrm{NH}_{4}^{+}$flux rates were estimated by measurement of intracellular $\mathrm{pH}$ changes in a linear portion of $\mathrm{pH}$ changes within the range of 5.54-6.93 for $\mathrm{H}^{+}$extrusion and 7.53-5.54 for $\mathrm{NH}_{4}^{+}$influx. Intracellular buffering capacities could not be determined due to the lack of an effective direct inhibitor of the $\mathrm{Na}^{+}$-independent $\mathrm{H}^{+}$extrusion described here. If not stated otherwise, data are expressed as mean \pm SEM with the indicated $n$.

Experiments were performed in nominally $\mathrm{CO}_{2} / \mathrm{HCO}_{3}^{-}$-free conditions, only on viable multinucleated cells which were attached to glass or bone and capable of hydrolyzing and retaining the $\mathrm{pH}$-sensitive dye. Cells selected for experiments were visualized by BCECF fluorescence and had diameters $>3 \times$ of mononuclear cells. In situ, visible bone resorption pits were observed underneath many untreated cells and such cells were preferentially chosen for the experiments. Postexperimental TRAP staining (32) was used after some experiments when resorption pits were not visible or the nature of the cells was uncertain.

Isolation of membrane vesicles from osteoclastic cells and measurements of $\mathrm{H}^{+}$pump activity. After cocultivation of $1.6 \times 10^{6}$ calvaria derived osteoblasts and $4 \times 10^{6}$ bone marrow cells in $15-\mathrm{cm}$ plastic dishes ( similar as above) the osteoclasts were partially purified by collagenase-dispase treatment for $20 \mathrm{~min}$ at $37^{\circ} \mathrm{C}$, followed by vigorous pipetting to remove the osteoblastic cells. Thereafter, the enriched osteoclast cell population was harvested and homogenized in a homogenizing buffer ( $300 \mathrm{mM}$ mannitol; $12 \mathrm{mM}$ Hepes/Tris; $\mathrm{pH}=7.4$ ) with a glass/ teflon Potter homogenizer $\left(4^{\circ} \mathrm{C} ; 20\right.$ strokes; high speed). The homogenate was centrifuged at $1,500 \mathrm{~g}$ for $15 \mathrm{~min}$ at $4^{\circ} \mathrm{C}$ in a desktop centrifuge with a swinging rotor (GPR centrifuge; Beckman Instruments, Inc. Ful-

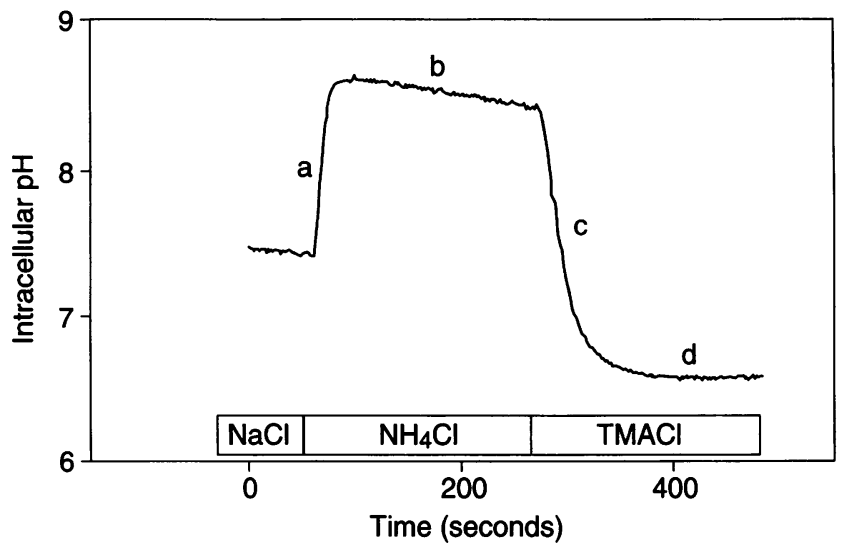

Figure 1. Absence of $\mathrm{Na}^{+}$-independent acid extrusion in rat osteoclasts plated on glass. Osteoclast perfusion with a $\mathrm{NH}_{4} \mathrm{Cl}$ solution (see Methods) induces a rapid intracellular alkalinization (trace $a$ ), followed by a slow acidification (trace $b ; 0.03 \pm 0.01 \mathrm{pH} \mathrm{U} / \mathrm{min}, n=60$ ). Upon removal of $\mathrm{NH}_{4} \mathrm{Cl}$, a further rapid acidification occurs (trace $c$ ) with very limited or no $\mathrm{pH}_{\mathrm{i}}$ recovery in a $\mathrm{Na}^{+}$-free medium (TMACl; trace $d ; 0.043 \pm 0.007 ; n=26$ ). In $90 \%$ of osteoclasts on glass the $\mathrm{H}^{+}$extrusion rate was under these conditions below $0.020 \mathrm{pH} \mathrm{U} / \mathrm{min}$.

lerton, CA). The supernatant was centrifuged at $27,000 \mathrm{~g}$ for $25 \mathrm{~min}$ at $4^{\circ} \mathrm{C}$ (JA-20 fixed angle rotor, centrifuge J2-21; Beckman Instruments, Inc.) and the pellet was resuspended in a buffer $(100 \mathrm{mM}$ mannitol, $100 \mathrm{mM} \mathrm{KCl}, 3$ Hepes/Tris; $\mathrm{pH}=7.0)$ using a Potter homogenizer $(20$ strokes, high speed at $\left.4^{\circ} \mathrm{C}\right)$. The homogenate was centrifuged $(27,000 \mathrm{~g}$ for $25 \mathrm{~min}$ at $4^{\circ} \mathrm{C}$ in JA-20 rotor) and the pellet was resuspended in the same buffer. Membrane vesicles were additionally dispersed with an insulin syringe $(20 \times)$ and left to equilibrate for $2 \mathrm{~h}$ at room temperature. Protein was determined using the BCA assay (Pierce Chemical Co., Rockford, IL).

Formation and dissipation of $\mathrm{H}^{+}$gradients was visualized by acridine orange fluorescence. Fluorometric experiments (PTI Deltascan; $\lambda_{e x}$ $\left.=493 ; \lambda_{e m}=525\right)$ were performed in a cuvette heated at $37^{\circ} \mathrm{C}$ equipped with a magnetic stirrer. An aliquot of membrane vesicles was diluted in $2 \mathrm{ml}$ of measuring buffer: $100 \mathrm{mM}$ mannitol, $100 \mathrm{mM} \mathrm{KCl}, 1 \mathrm{mM}$ ATP, 20 Hepes/Tris; $\mathrm{pH}=7.0,5 \mathrm{mM}$ valinomycin, $6 \mathrm{mM}$ acridine orange, and $5 \mathrm{mM} \mathrm{MgCl}{ }_{2}$ which was used to initiate the $\mathrm{H}^{+}$pumping. The data were collected by a computer at 1-3-s intervals using PTI software.

\section{Results}

Individual osteoclasts, loaded with the $\mathrm{pH}$-sensitive fluorescent dye BCECF, were examined for their ability to extrude acid after $\mathrm{NH}_{4}^{+}$-induced acid loading (33). In the presence of extracellular $\mathrm{Na}^{+}$, most cells throughout the organism have the capacity to restore their $\mathrm{pH}_{\mathrm{i}}$ after such treatment via the almost ubiquitous $\mathrm{Na}^{+} / \mathrm{H}^{+}$exchanger (34). However, only cells that have an additional mechanism for acid extrusion or $\mathrm{HCO}_{3}^{-}$intake, such as macrophages, kidney, or gastric parietal cells, can restore their physiological $\mathrm{pH}_{\mathrm{i}}$ in the absence of $\mathrm{Na}^{+}$. Since osteoclasts are thought to secrete acid during bone resorption via a $\mathrm{Na}^{+}$-independent $\mathrm{H}^{+}$pump (7), we tested this capacity for acid extrusion in the nominal absence of extracellular $\mathrm{HCO}_{3}^{-}$and $\mathrm{Na}^{+}$.

In cells plated on glass the addition of $\mathrm{Na}^{+}$-free $\mathrm{NH}_{4}^{+}$solution causes an elevation in $\mathrm{pH}_{\mathrm{i}}$ (Fig. 1, trace $a$ ), attributed to the high $\mathrm{NH}_{3}: \mathrm{NH}_{4}^{+}$permeability ratio (33). This response occurs in most cell types because of limited entry pathways for 

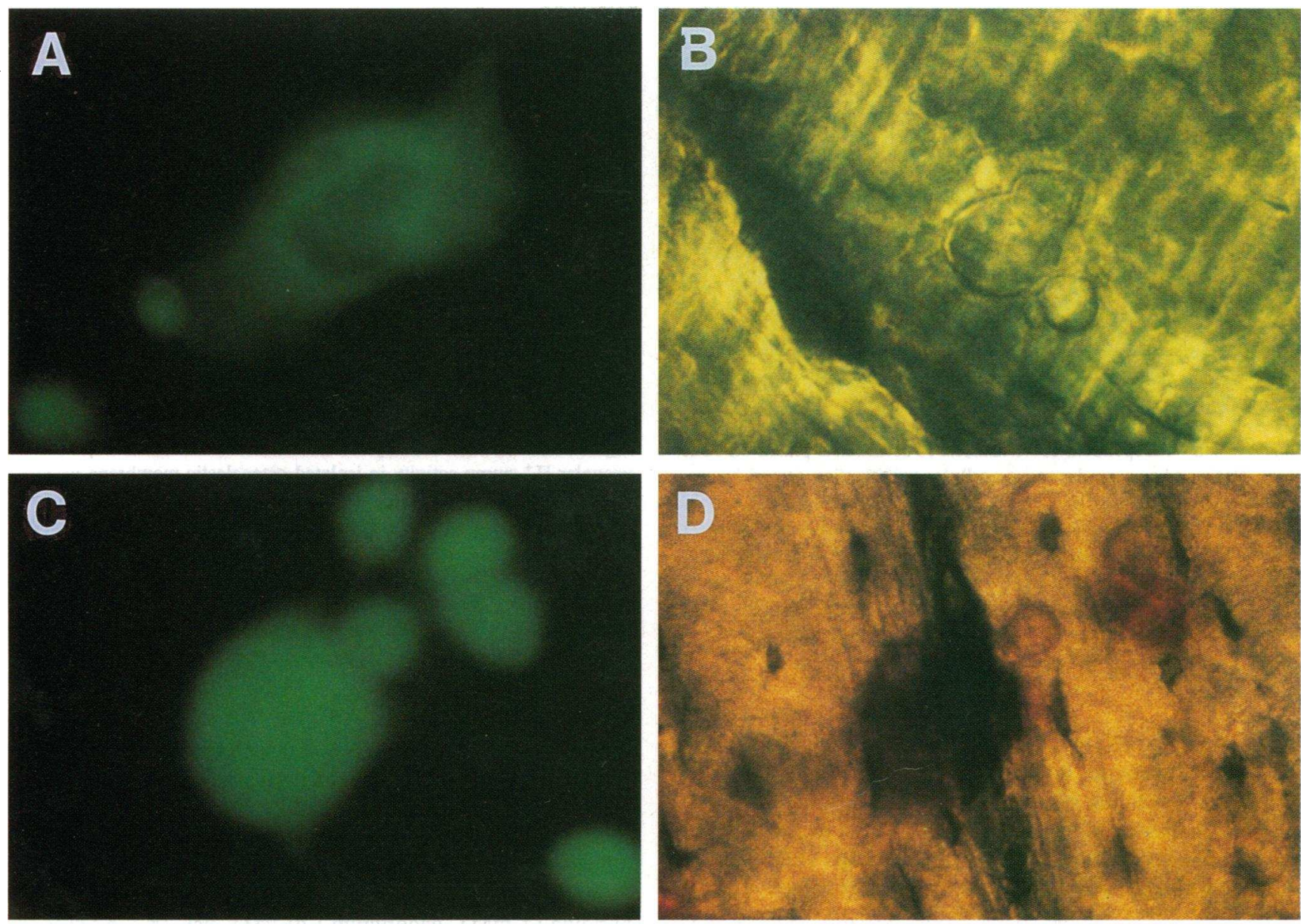

Figure 2. Visualization of osteoclasts on bone slices, loaded with BCECF and stained for TRAP. ( $A$ and $C$ ) Cells attached to bone slices and loaded with $5 \mathrm{mM} \mathrm{BCECF}\left(\lambda_{e x}=495\right.$ and $440 \mathrm{~nm} ; \lambda_{e m}=520 \mathrm{~nm}$ ) were used for measurements in this study. With monochromator generated excitation no significant background fluorescence from bone was observed; the signal to background ratio $>10(B)$ A resorption pit underneath the cell in $A$. (D) Same cell as in $B$ is stained for TRAP.

$\mathrm{NH}_{4}^{+}$. After rapid alkalinization in osteoclasts, a slower acidification occurs $(0.030 \pm 0.010 \mathrm{pH} \mathrm{U} / \mathrm{min}, n=60)$, due to $\mathrm{NH}_{4}^{+}$ influx (Fig. 1, trace $b$ ). This slow $\mathrm{NH}_{4}^{+}$influx was attenuated by a mixture of $\mathrm{K}^{+}$channel blockers ( $1 \mathrm{mM}$ 4-aminopyridine and $10 \mathrm{mM}$ tetraethylammonium; Zimolo, G.A. Rodan, unpublished observation). Upon removal of extracellular $\mathrm{NH}_{4}^{+}$, the $\mathrm{pH}_{\mathrm{i}}$ drops below the resting $\mathrm{pH}_{\mathrm{i}}$ (Fig. 2, trace $c$ ) due to a rapid $\mathrm{NH}_{3}$ exit. $90 \%$ of osteoclasts examined could not efficiently recover their $\mathrm{pH}_{\mathrm{i}}$ in the absence of $\mathrm{Na}^{+}\left(<0.020 \mathrm{pH}_{\mathrm{i}} \mathrm{U} / \mathrm{min}\right)$, indicating that active $\mathrm{Na}^{+}$-independent acid extrusion was generally absent in the plasma membrane of these cells. Since extracellular $\mathrm{H}^{+}$inhibits $\mathrm{Na}^{+} / \mathrm{H}^{+}$exchange $(34,35)$, that process is not likely to be responsible for the acidification of the resorption pit. It was, therefore, surprising that in these cells, which form erosion pits when seeded on bone, we could not detect $\mathrm{Na}^{+}$-independent $\mathrm{H}^{+}$extrusion. In an effort to explain this apparent paradox we repeated the same experiments in osteoclasts plated on bone slices. With appropriate monochromatic excitation and restricted emission, no significant bone autofluorescence was observed (Fig. 2, $A$ and $C$ ), a frequently encountered obstacle with broader excitation/emmission spectra (i.e., with a mercury lamp and a dichroic mirror). After 12$\mathrm{h}$ attachment to bone and BCECF loading, the largest cells in the field were chosen for examination. Pits were frequently observed by phase contrast microscopy underneath such cells and selection was always aimed at those cells (Fig. $2 \mathrm{~B}$ ). In some experiments, the pits were not visible and the identity of these cells was confirmed by postexperimental TRAP staining in situ (Fig. $2 \mathrm{D}$ ). For osteoclasts generated in culture, every cell that had a diameter three times that of the mononucleated cell or larger was TRAP positive. About one-third of the data were collected on primary rat osteoclasts and the remainder on mouse bone marrow-derived osteoclasts. No significant qualitative or quantitative differences were observed between the two species.

The $\mathrm{pH}_{\mathrm{i}}$ changes produced by an $\mathrm{Na}^{+}$-free $\mathrm{NH}_{4}^{+}$solution in OCs attached to bone differed from those in OCs attached to glass. In OCs on bone, there was no or very little alkalinization (Fig. 3, trace a) followed by an immediate acidification (Fig. 3, trace $b$ ), at the mean rate of $0.550 \pm 0.130 \mathrm{pH} \mathrm{U} / \mathrm{min}$, $n=27$, indicating a significant influx pathway for $\mathrm{NH}_{4}^{+}$. After removal of $\mathrm{NH}_{4}^{+}$and intracellular acidification (Fig. 3, trace c) most cells on bone had the ability to restore their $\mathrm{pH}_{\mathrm{i}}$ in the absence of $\mathrm{Na}^{+}$(fig. 3, trace $d$ ) at a mean rate of $0.228 \pm 0.011$ pH U/min, $n=25$. This $\mathrm{Na}^{+}$-independent $\mathrm{H}^{+}$-recovery observed in nominally $\mathrm{HCO}_{3}^{-}$-free medium is attributed to $\mathrm{H}^{+}$ pumping. This $\mathrm{pH}_{\mathrm{i}}$ recovery was not inhibited by $\mathrm{H}_{2}$ DIDS ( 100 $\mu \mathrm{M}$; not shown), thereby excluding the possibility that intracel- 


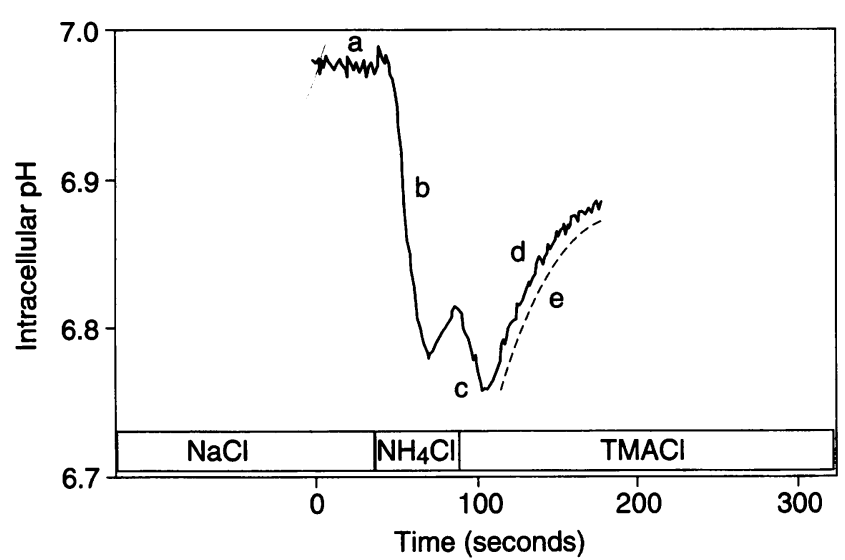

Figure 3. $\mathrm{Na}^{+}$-independent $\mathrm{H}^{+}$extrusion in osteoclasts plated on bone slices. $\mathrm{NH}^{+}$addition produces intracellular acidification (trace $b$; $0.550 \pm 0.130 \mathrm{pH} \mathrm{U} / \mathrm{min}, n=27$ ), after brief alkalinization (trace $a$ ), which is sometimes absent. $\mathrm{NH}_{4}{ }^{+}$removal causes further acidification (trace $c$ ) followed by spontaneous recovery in a $\mathrm{Na}^{+}$-free medium (TMACl; trace $d ; 0.228 \pm 0.011 \mathrm{pH} \mathrm{U} / \mathrm{min}, n=25$ ). $10^{-7} \mathrm{M}$ bafilomycin $\mathrm{A}_{1}$ fails to significantly inhibit this $\mathrm{H}^{+}$extrusion (trace $e$ ). This is a representative trace of measurements from 25 separate cells.

lularly generated $\mathrm{CO}_{2} / \mathrm{HCO}_{3}^{-}$and the anion exchanger play a direct or indirect role in this process. Surprisingly however, this transport was not significantly inhibited by the macrolide antibiotic bafilomycin $A_{1}$ (at up to $10^{-7} \mathrm{M}$ ), a membrane permeable inhibitor of the vacuolar $(\mathrm{V}) \mathrm{H}^{+}$pumps (Fig. 3, trace $e)$. The same bafilomycin solutions were fully effective in inhibiting the $(\mathrm{V}) \mathrm{H}^{+}$pump of rat kidney proximal tubule cells (data not shown; see reference $36,36 \mathrm{a}$ ). Incubation with a higher concentration of bafilomycin $A_{1}\left(10^{-5} \mathrm{M}\right)$ for $20 \mathrm{~min}$ or more at $37^{\circ} \mathrm{C}$ was inhibitory, but at these concentrations this agent is not selective and affects other ATPases, i.e., $\mathrm{Na}^{+} / \mathrm{K}^{+}$ATPase, $\mathrm{Ca}^{2+}$-ATPase, etc. (12). Finally, resting $\mathrm{pH}_{\mathrm{i}}$ was not increased after removal of $\mathrm{Na}^{+}$(tetramethylammonium replacement) neither in osteoclasts attached to bone nor glass (data not shown).

To try to reconcile these observations with the reported presence of bafilomycin $\mathrm{A}_{1}$-sensitive $\mathrm{H}^{+}$transport in osteoclastderived vesicles $(7-11)$ we prepared membrane vesicles from a highly enriched population of the mouse osteoclasts used here ( see Methods). Bafilomycin $\mathrm{A}_{1}$-sensitive $\mathrm{H}^{+}$transport was clearly demonstrated in this preparation and under the same conditions no bafilomycin-insensitive mechanism was present (Fig. 4). The observed $\mathrm{H}^{+}$pumping was insensitive to $1 \mathrm{mM}$ ALN and under our conditions no bafilomycin-insensitive transport was observed. These data suggest that although a bafilomycin sensitive vacuolar $\mathrm{H}^{+}$pump is present in these cells, it does not appear to mediate most of the $\mathrm{Na}^{+}$-independent acid extrusion, reflected in $\mathrm{pH}_{\mathrm{i}}$ changes, in the whole osteoclasts seeded on bone.

The distribution of $\mathrm{Na}^{+}$-independent $\mathrm{H}^{+}$extrusion rates in cells attached to bone versus glass in shown in Fig. $5 . \mathrm{H}^{+}$ extrusion was detectable in most osteoclasts on bone and was absent or significantly lower in cells on glass. For reasons that are not known, the range of $\mathrm{pH}_{\mathrm{i}}$ recovery rates was large (from 0 to $1 \mathrm{pH} \mathrm{U} / \mathrm{min}$ ).

Fig. 6 shows that osteoclasts on bone had a significant $\mathrm{NH}_{4}^{+}$influx pathway that showed a positive correlation with the

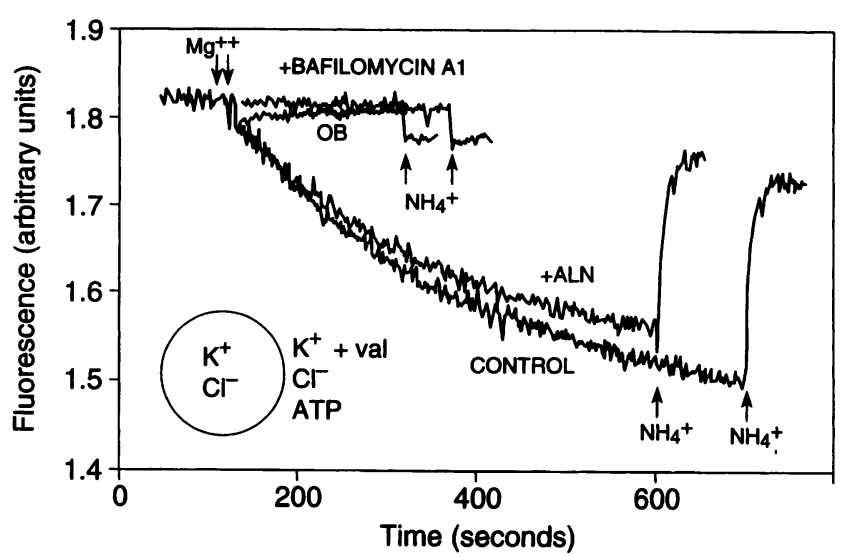

Figure 4. Effects of bafilomycin and alendronate on ATP-dependent vacuolar $\mathrm{H}^{+}$-pump activity in isolated osteoclastic membrane vesicles. Acridine orange quenching shows $\mathrm{Mg}^{2+}$-dependent $\mathrm{H}^{+}$-ATPase activity in inside out vesicles that is bafilomycin $A_{1}$ sensitive $\left(10^{-8} \mathrm{M}\right)$ and alendronate ( $1 \mathrm{mM}$ ) insensitive. $75 \mathrm{mg}$ protein was used per experiment. Membrane vesicles isolated from osteoblasts alone, used for co-culture of cells, did not show acidification $(O B) . \mathrm{NH}_{4} \mathrm{Cl}(50 \mathrm{mM})$ was used to dissipate the $\mathrm{H}^{+}$gradient. This is a representative figure of six traces from two independent membrane preparations.

presence and the rate of $\mathrm{Na}^{+}$-independent $\mathrm{H}^{+}$extrusion $(r$ $=0.80$ ), but the nature of this pathway remains to be elucidated. Due to similar hydrated ionic radii (37), $\mathrm{NH}_{4}^{+}$and $\mathrm{K}^{+}$could share similar transmembrane pathways; however, the observed influx was not significantly modified by modulators of $\mathrm{K}^{+}$ fluxes, including $\mathrm{K}^{+}$channel blockers TEA $(10 \mathrm{mM})$, 4-aminopyridine $(1 \mathrm{mM})$, gadolinium $(20 \mu \mathrm{M}), \mathrm{Na}^{+} / \mathrm{K}^{+}$ATPase inhibitor ouabain $(1 \mathrm{mM})$, and $\mathrm{Na}^{+}, \mathrm{K}^{+} / 2 \mathrm{Cl}^{-}$transport inhibitor furosemide $(1 \mathrm{mM})$. It is possible that these inhibitors might not have reached their target if it is located on the ruffled border inside the sealed lacuna.

Calcitonin effects on $\mathrm{Na}^{+}$-independent $\mathrm{H}^{+}$extrusion. Osteoclasts attached to bone for $12 \mathrm{~h}$ were treated with salmon calcitonin $\left(10^{-8} \mathrm{M}\right)$ for $1 \mathrm{~h}$ at $37^{\circ} \mathrm{C}$ (Fig. 7) before loading with

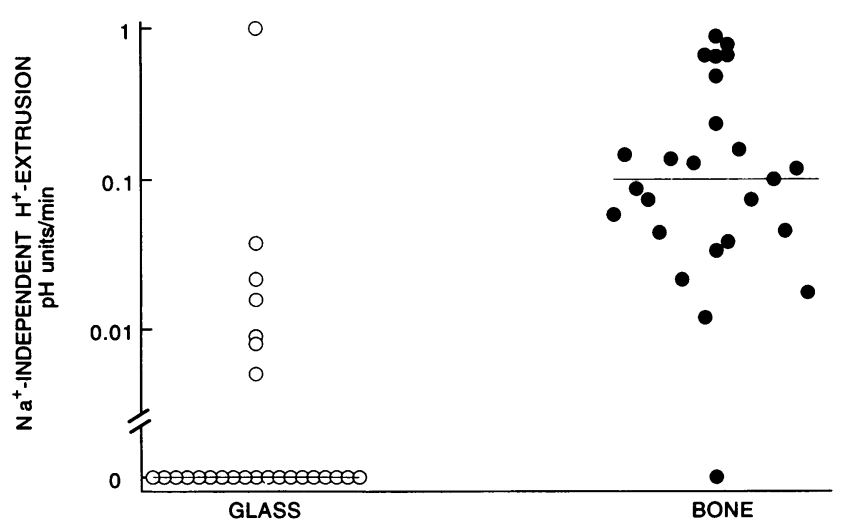

Figure 5. Distribution of $\mathrm{Na}^{+}$-independent $\mathrm{H}^{+}$extrusion rates in osteoclasts attached to bone or glass. The cells were attached to their substrate in the presence of $10 \%$ FBS and after $12 \mathrm{~h}$ the measurements were performed under serum free conditions as described in Methods. Medians are shown as horizontal lines. $\mathrm{Na}^{+}$-independent $\mathrm{H}^{+}$extrusion on glass: $0.043 \pm 0.007 \mathrm{pH} \mathrm{U} / \mathrm{min}, n=26$. $\mathrm{Na}^{+}$-independent $\mathrm{H}^{+}$extrusion on bone: $0.233 \pm 0.051 \mathrm{pH} \mathrm{U} / \mathrm{min}, n=27$. Note the logarithmic scale. 


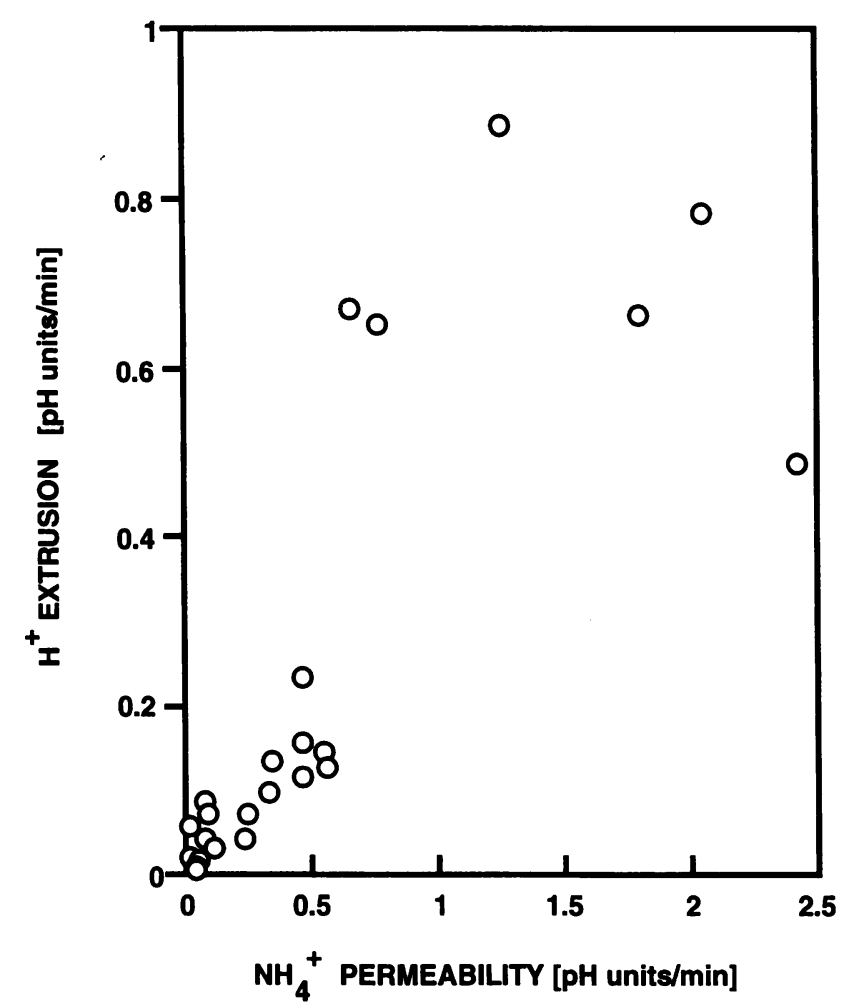

Figure 6. Correlation of $\mathrm{NH}_{4}{ }^{+}$influx and $\mathrm{Na}^{+}$-independent $\mathrm{H}^{+}$extrusion in osteoclasts attached to bone. The exact pathway for $\mathrm{NH}_{4}{ }^{+}$influx has not yet been established (see text) but its presence correlates with that of $\mathrm{Na}^{+}$-independent $\mathrm{H}^{+}$extrusion $(r=0.80)$.

BCECF. The calcitonin-treated osteoclasts did not extrude acid under $\mathrm{Na}^{+}$-free conditions, their $\mathrm{pH}_{\mathrm{i}}$ regulation being similar to that of osteoclasts attached to glass. With $10^{-12} \mathrm{M}$ calcitonin (not shown) the inhibition was present, but not complete as with $10^{-8} \mathrm{M}$ (acid extrusion rate medians: $0.001 \mathrm{pH} \mathrm{U} / \mathrm{min}$ for $10^{-8} \mathrm{M}$ and $\left.0.03 \mathrm{pH} \mathrm{U} / \mathrm{min} 10^{-12} \mathrm{M}, n=4\right)$.

Effects of $\mathrm{ALN}$ on $\mathrm{Na}^{+}$-independent $\mathrm{H}^{+}$extrusion. When cells were attached to bone slices preincubated in ALN, con-

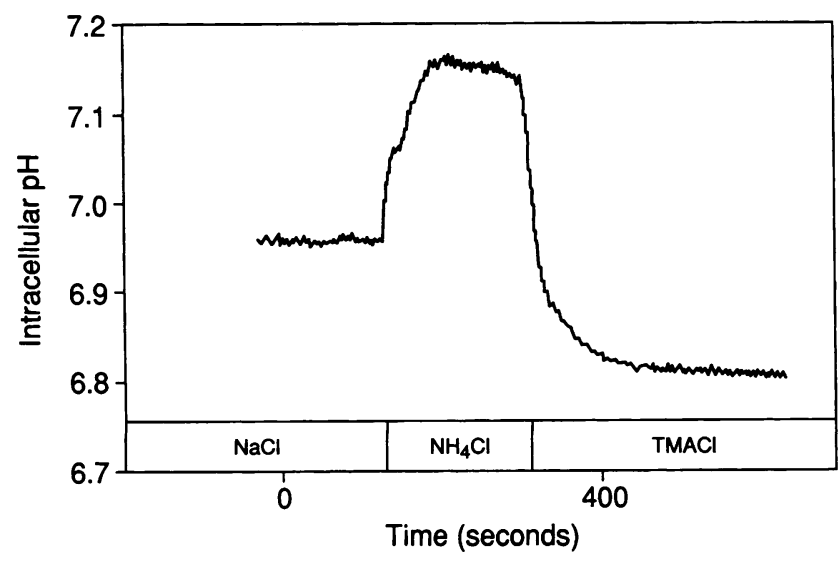

Figure 7. Calcitonin inhibits $\mathrm{Na}^{+}$-independent $\mathrm{H}^{+}$extrusion in osteoclasts on bone. Osteoclasts attached to bone were incubated with salmon calcitonin $\left(10^{-8} \mathrm{M}\right)$ for $1 \mathrm{~h}$ at $37^{\circ} \mathrm{C}$ followed by loading with BCECF. After intracellular acidification by $\mathrm{NH}_{4}{ }^{+}$pulse, $\mathrm{Na}^{+}$-independent $\mathrm{pH}_{\mathrm{i}}$ recovery was measured and found absent $(n=4)$.

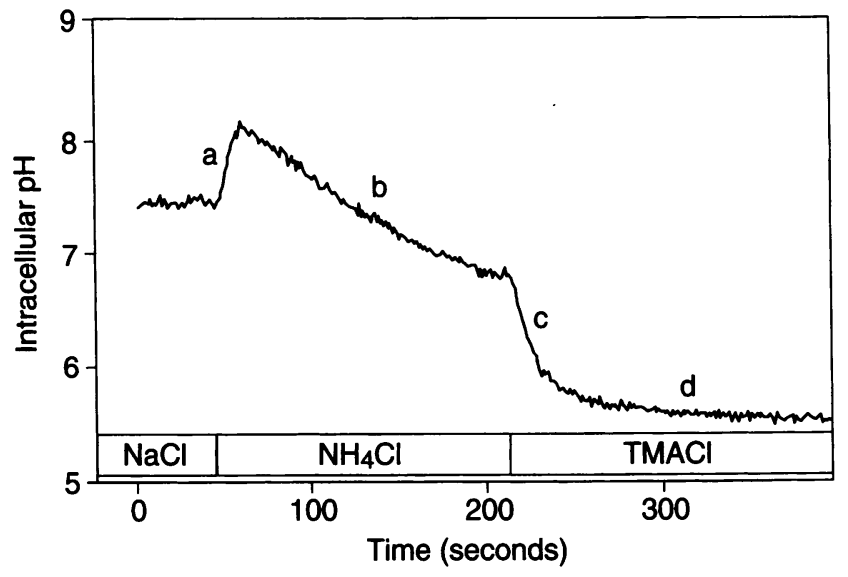

Figure 8. Presence of ALN on bone slices abolishes $\mathrm{Na}^{+}$-independent $\mathrm{H}^{+}$extrusion. Osteoclasts attached for $12 \mathrm{~h}$ to a bone slice with prebound ALN $0.22 \mathrm{nmol} / \mathrm{mm}^{2}$ show no $\mathrm{Na}^{+}$-independent $\mathrm{H}^{+}$extrusion $(0.004 \pm 0.000 \mathrm{pH} \mathrm{U} / \mathrm{min}, n=21)$. A control trace on bone without ALN is depicted in Fig. 3. This is a representative trace from experiments on 23 separate cells. The abbreviations a,b,c,d are explained in Fig. 1.

taining $0.22 \mathrm{nmol} \mathrm{ALN} / \mathrm{mm}^{2}$ bone, no $\mathrm{Na}^{+}$-independent $\mathrm{H}^{+}$ extrusion was observed (Fig. 8). A time course for this inhibitory effect was conducted at $0.22 \mathrm{nmol} \mathrm{ALN} / \mathrm{mm}^{2}$ bone. The earliest effect was observed at $2.5 \mathrm{~h}$ after cell seeding, the time required for cell attachment, BCECF loading and the assembly of the measuring chamber. The ALN effects were dose dependent with a $50 \%$ inhibitory dose being around $0.022 \mathrm{pmol} / \mathrm{mm}^{2}$ bone (Fig. 9). Etidronate (1-hydroxyethylidene-1,1--bisphosphonate), another bisphosphonate, had similar effects at 2.2 $\mathrm{nmol} / \mathrm{mm}^{2}$ bone.

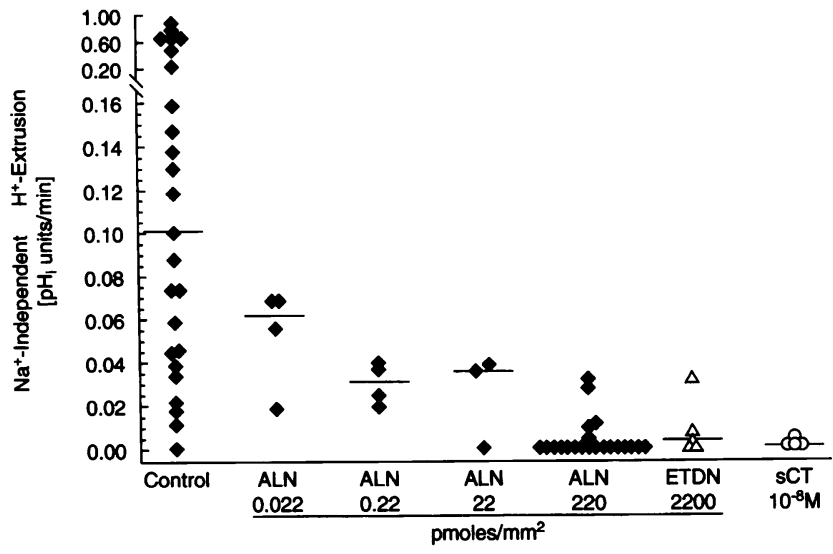

Figure 9. Alendronate, etidronate, and calcitonin effects on $\mathrm{Na}^{+}$-independent $\mathrm{H}^{+}$extrusion rates on bone. Summary of individual experiments on bone is shown. Salmon calcitonin $\left(10^{-8} \mathrm{M}\right)$, similarly to alendronate causes inhibition of $\mathrm{Na}^{+}$-independent $\mathrm{H}^{+}$extrusion on bone after 60 min incubation at $37^{\circ} \mathrm{C}$ followed by BCECF loading. Alendronate inhibition increases with the amount of ALN bound to bone, with $50 \%$ inhibitory effects observed $\sim 0.022 \mathrm{pmol} / \mathrm{mm}^{2}$ bone after $12 \mathrm{~h}$ attachment. Another bisphosphonate, etidronate displays similar effects to alendronate. The horizontal lines represent median values. Controls on bone are from Fig. 2 for reference. 


\section{Discussion}

This study describes a potent $\mathrm{Na}^{+}$-independent acid extrusion mechanism in osteoclasts, which is induced by osteoclast attachment to bone and is inactive in osteoclasts treated with salmon calcitonin or seeded on bone preincubated in bisphosphonate. Using restricted monochromatic excitation light and restricted emission we were able to visualize osteoclasts loaded with BCECF with negligible detection of bone autofluorescence. To single out the osteoclasts, the biggest cell in the field was chosen for these experiments. These cells had been seeded on bone 12 $h$ earlier, and under many there were visible resorption pits. TRAP staining was performed on a sample of cells for confirmation of osteoclastic phenotype, especially in cells treated with ALN, which had no resorption pits. Only viable cells were tested, as estimated by their attachment, by esterase activity and by membrane integrity, evidenced by BCECF retention.

We observed that these osteoclastic cells exhibit at least two patterns of $\mathrm{pH}_{\mathrm{i}}$ regulation. On glass, like most other cell types, they do not extrude acid in an $\mathrm{Na}^{+}$and $\mathrm{HCO}_{3}^{-}$-independent manner. However, upon attachment to bone, an $\mathrm{Na}^{+}$-independent mechanism of acid extrusion is being activated. This $\mathrm{H}^{+}$ extrusion is similar to that of cells that have proton pumping capability $(36,38,39)$. The mechanism for acquiring the $\mathrm{H}^{+}-$ pumping ability on bone may result from osteoclast polarization, with the formation of a specialized new membrane in which the ion pathways have been inserted. Several membrane transport processes, including $\mathrm{H}^{+}$pumps, have been reported to be regulated by insertion/removal into the plasma membrane (40). Moreover, membrane capacitance measured by patch clamping indicates that osteoclasts have an increased plasma membrane surface on bone, consistent with the presence of a ruffled border (41).

The coactivation of a $\mathrm{NH}_{4}^{+}$-permeable pathway which correlates with the appearance of the acid extruder, might reflect simultaneous activation or insertion into the ruffled membrane. This pathway probably transports a different ion in vivo. It has been suggested that $\mathrm{NH}_{4}^{+}$is translocated via $\mathrm{K}^{+}$pathways, but in this study it was insensitive to several $\mathrm{K}^{+}$pathway blockers. This could also be due to the inaccessibility of the inhibitors to their target. The $\mathrm{NH}_{4}^{+}$uptake could represent a charge compensatory pathway, but as yet we have no evidence for a causal relation between $\mathrm{NH}_{4}^{+}$uptake and the $\mathrm{H}^{+}$extrusion observed here.

Surprisingly, the bulk of the $\mathrm{Na}^{+}$-independent $\mathrm{H}^{+}$extrusion observed in our whole cell assays was bafilomycin $\mathrm{A}_{1}$ insensitive (Fig. 3). A bafilomycin highly sensitive $\mathrm{H}^{+}$-ATPase clearly exists in osteoclasts $(7,9-11)$ and we demonstrated its presence in vesicles prepared from the osteoclasts used in this study. However, the findings reported here suggest the existence of an alternative or additional bafilomycin-insensitive $\mathrm{H}^{+}$extruder in whole osteoclasts that was not detectable under our conditions in isolated membrane vesicles. The reported inhibition of bone resorption by bafilomycin (42) could occur via other bafilomycin effects; for example, on vesicular traffic (4345 ). Alternative $\mathrm{H}^{+}$pathways have also been observed in several phagocytic cells (46). Moreover, in osteoclasts, numerous bafilomycin-insensitive acidic vacuoles (47) and some alternative forms of vacuolar pumps have been reported $(16,17)$. The existence of bafilomycin-insensitive $\mathrm{H}^{+}$extrusion pathway in osteoclasts was previously reported by us (36a) and others (48).
The $\mathrm{Na}^{+}$-independent $\mathrm{H}^{+}$extrusion observed here was inhibited by calcitonin (Figs. 7 and 9 ) which suggests that it may play a role in the bone resorption process. Moreover, bone pretreatment with a potent bone resorption inhibitor, the aminobisphosphonate ALN, produced a similar effect and reverted osteoclast behavior to that seen on glass, analogous to that of most other cell types without $\mathrm{Na}^{+}$- independent $\mathrm{H}^{+}$-extruders (33). This observation further supports a relationship between $\mathrm{H}^{+}$extrusion and bone resorption. It also provides a clear demonstration of an alendronate effect on a discrete physiological process in an isolated osteoclast. Our findings do not exclude indirect effects of bisphosphonates via osteoblasts (28), but focus on the events occurring at the osteoclast level. The molecular mechanism for the $\mathrm{H}^{+}$extrusion observed here, which may reflect osteoclast activation, has not been elucidated. Alendronate and calcitonin produce in osteoclasts (3-5) similar morphological changes to those caused by $\operatorname{src}$ knockout in mice where the lack of ruffled membrane is associated with compromised bone resorption (6). The ruffled membrane is probably formed by the insertion of vesicles which could contain the $\mathrm{H}^{+}$extrusion apparatus detected here. Due to the similarity in the structure of several bisphosphonates to nucleoside phosphates, their putative target could include kinases (6), such as phosphatidyl inositol-3-kinase (49), phosphatases, small GTPases (44) such as rho (50), or some other molecule that may play a role in the ruffled border formation and the acid extrusion described in this paper.

In conclusion, we demonstrate that upon osteoclastic attachment to bone, osteoclasts display a strong $\mathrm{Na}^{+}$-independent acid extrusion mechanism. This process is inhibited by calcitonin, and by pretreatment of bone with alendronate. In addition, these observations provide an experimental system for studying osteoclast activation and for identification of the molecular target(s) of bisphosphonates or other osteoclast inhibitors.

\section{Acknowledgments}

We thank Dr. Sevgi Rodan and Dr. Charles Cohen for their valuable discussions and critical comments.

\section{References}

1. Kanehisa, J., and J. N. M. Heersche. 1988. Osteoclastic bone resorption: in vitro analysis of resorption and migration of individual osteoclasts. Bone. 9:7379.

2. Miller, S. C., and W. S. S. Jee. 1979. The effect of dichloromethylene diphosphonate, a pyrophosphate analog, on bone and bone cell structure in the growing rat. Anat. Rec. 193:439-462.

3. Sato, M., W. Grasser, N. Endo, R. Akins, H. Simmons, D. D. Thompson, E. Golub, and G. A. Rodan. 1991. Bisphosphonate action: alendronate localization in rat bone and effects on osteoclast ultrastructure. J. Clin. Invest. 88:2095-2105.

4. Kallio, D. M., P. R. Garant, and C. Minkin. 1972. Ultrastructural effects of calcitonin on osteoclasts in tissue culture. J. Ultrast. Res. 39:205-216.

5. Raisz, L. G., W. Y. W. Au, J. Friedman, and I. Niemann. 1967. Thyrocalcitonin and bone resorption. Am. J. Med. 43:684-690.

6. Soriano, P., C. Montgomery, R. Geske, and A. Bradley. 1991. Targeted disruption of the c-src proto-oncogene leads to osteopetrosis in mice. Cell. 64:693-702.

7. Blair, H. C., S. L. Teitelbaum, R. Ghiselli, and S. Gluck. 1989. Osteoclastic bone resorption by a polarized vacuolar proton pump. Science (Wash. DC) 245:855-857.

8. Bekker, P. J., and C. V. Gay. 1990. Biochemical characterization of an electrogenic vacuolar proton pump in purified chicken osteoclast plasma membrane vesicles. J. Bone Miner. Res. 5:569-579.

9. Mattsson, J. P., P. Lorentzon, B. Wallmark, and D. J. Keeling. 1993. Characterization of proton transport in bone-derived membrane vesicles. Biochem. Biophys. Acta. 1146:106-112.

10. Väänänen, H. K., E. K. Karhukorpi, K. Sundquist, B. Wallmark, I. Roini- 
nen, T. Hentunen, J. Tuukkanen, and P. Lakkakorpi. 1990. Evidence for the presence of a proton pump of the vacuolar $\mathrm{H}^{+}$-ATPase type in the ruffled borders of osteoclasts. J. Cell Biol. 111:1305-1311.

11. Wang, Z.-Q., P. Hemken, D. Menton, and S. Gluck. 1992. Expression of vacuolar $\mathrm{H}^{+}$-ATPase in mouse osteoclasts during in vitro differentiation. Am. J. Physiol. 263:F227-283.

12. Bowman, E. J., A. Siebers and K. Altendorf. 1988. Bafilomycins: A class of inhibitors, of membrane ATPases from microorganisms, animal cells, and plant cells. Proc. Natl. Acad. Sci. USA. 85:7972-7976.

13. Hanada, H., Y. Moriyama, M. Maeda, and M. Futai. 1990. Kinetic studies of chromaffin granule $\mathrm{H}^{+}$-ATPase and effects of bafilomycin $\mathrm{A}_{1}$. Biochem. Biophys. Res. Commun. 170:873-878.

14. Rautiala, T. J., A. M. Koskinen, and H. K. Väänänen. 1993. Purification of vacuolar ATPase with bafilomycin $\mathrm{Cl}$ affinity chromatography. Biochem. Biophys. Res. Commun. 194:50-56.

15. Forgac, M. 1989. Structure and function of vacuolar class of ATP-driven proton pumps. Physiol. Rev. 69:765-796.

16. Chatterjee, D., M. Chakraborty, M. Leit, M. Neff, S. Jamsa-Kellokumpu, R. Fuchs, and R. Baron. 1992. Sensitivity to vanadate and isoforms of subunits $A$ and $B$ distinguish the osteoclast proton pump from other vacuolar $\mathrm{H}^{+}$ATPases. Proc. Natl. Acad. Sci. USA. 89:6257-6261.

17. van Hille, B., H. Richener, D. B. Evans, J. R. Green, and G. Bilbe. 1993 Identification of two subunit $\mathrm{A}$ isoforms of the vacuolar $\mathrm{H}^{+}$-ATPase in human osteoclastoma. J. Biol. Chem. 268:7075-7080.

18. Balena, R., B. C. Toolan, M. Shea, A. Markatos, E. R. Myers, S. C. Lee, E. E. Opas, J. G. Seedor, H. Klein, D. Frankenfield, et al. 1993. The effects of two-year treatment with aminobisphosphonate alendronate on bone metabolism, bone histomorphometry and bone strength in ovariectomized nonhuman primates. J. Clin. Invest. 92:2577-2586.

19. Fleisch, H., R. G. G. Russell, and M. D. Francis. 1969. Diphosphonates inhibit hydroxyapatite dissolution in vitro and bone resorption in vivo. Science (Wash. DC). 165:1262-1264.

20. Cecchini, M. G., R. Felix, H. Fleisch, and P. H. Cooper. 1987. Effect of bisphosphonates on proliferation and viability of mouse bone marrow-derived macrophages. J. Bone Miner. Res. 2:135-142.

21. Cecchini, M. G., and H. Fleisch. 1990. Bisphosphonates in vitro specifically inhibit, among the hematopoietic series, the development of the mouse mononuclear phagocyte lineage. 1990. J. Bone Miner. Res. 5:1019-1027.

22. Hughes, D. E., B. R. MacDonald, R. G. G. Russel, and M. Gowen. 1989. Inhibition of osteoclast-like cell formation by bisphosphonates in long-term cultures of human bone marrow. J. Clin. Invest. 83:1930-1935.

23. Löwik, C. W. G. M., G. Vander Plujim, L. J. A. Vander Wee-Pals, H. B V. T. De Groot, and O. L. M. Bijvoet. 1988. Migration and phenotypic transformation of osteoclast precursors into mature osteoclasts: The effect of a bisphosphonate. J. Bone. Miner. Res. 2:185-192.

24. Papapoulos, S. E., K. Hoekman, C. W. G. M. Löwik, P. Vermeij, and O. L. M. Bijvoet. 1989. Application of in vitro model and a clinical protocol in the assessment of the potency of a new bisphosphonate. J. Bone Miner. Res. 4:775-781.

25. Boonekamp, P. M., L. J. A. Vander Wee-Pals, M. M. L. van Wijk-van Lennep, C. W. Thesingh, and O. L. M. Bijvoet. 1986. Two modes of action of bisphosphonates on osteoclastic resorption of mineralized matrix. Bone and Miner. 1:27-39.

26. Flanagan, A. M., and T. J. Chambers. Dichloromethylenebisphosphonate (C12MBP) inhibits bone resorption through injury to osteoclasts that resorb C12MBP-coated bone. 1989. Bone and Miner. 6:33-43.

27. Carano, A., S. L. Teitelbaum, J. D. Konsek, P. H. Schlesinger, and H. C. Blair. Bisphosphonates directly inhibit the bone resorption activity of isolated avian osteoclasts in vitro. 1990. J. Clin. Invest. 85:456-461.

28. Sahni, M., H. L. Guenther, H. Fleisch, P. Collin, and T. J. Martin. 1993. Bisphosphonates act on rat bone resorption through mediation of osteoblasts. $J$. Clin. Invest. 91:2004-2011.

29. Takahashi, N., T. Akatsu, N. Udagawa, T. Sasaki, A. Yamaguchi, J. M.
Moseley, T. J. Martin, and T. Suda. 1988. Osteoblastic cells are involved in osteoclast formation. Endocrinology. 123:2600-2602.

30. Tanaka, H., M. Sato, D. Shinar, and G. A. Rodan. 1991 Echistatin inhibits osteoclast-like cell generation in the co-culture system of mouse osteoblastic cells and bone marrow cells. J. Bone Miner. Res. 6:S148.

31. Thomas, J. A., R. N. Buchsbaum, A. Zimniak, and E. Racker. 1979. Intracellular $\mathrm{pH}$ measurements in Ehrlich ascites tumor cells utilizing spectroscopic probes generated in situ. Biochemistry. 18:2210-2218.

32. Udagawa, N., N. Takahashi, T. Akatsu, T. Sasaki, A. Yamaguchi, H. Kodama, T. J. Martin, and T. Suda. 1989. The bone marrow-derived stromal cell lines MC3T3-G2/PA6 and ST2 support osteoclast-like cell differentiation in cocultures with mouse spleen cells. Endocrinology. 125:1805-1813.

33. Boron, W. F. and P. deWeer. 1976. Intracellular pH transients in squid giant axons caused by $\mathrm{CO}_{2}, \mathrm{NH}_{3}$ and metabolic inhibitors. J. Gen. Physiol. 67:91112.

34. Grinstein, S. 1988. $\mathrm{Na}^{+} / \mathrm{H}^{+}$Exchange. CRC Press, Inc., Boca Raton, FL.

35. Alpern, R. J. 1990. Cell mechanisms of proximal tubule acidification. Physiol. Rev. 70:79-114.

36. Zimolo, Z., M. H. Montrose, and H. Murer. 1992. $\mathrm{H}^{+}$extrusion by an apical vacuolar $\mathrm{H}^{+}$-ATPase in rat renal proximal tubules. J. Membrane Biol. 126:19-26.

36a. Zimolo, Z., G. Wesolowski, and G. A. Rodan. 1992. J. Bone Miner. Res. 7(S1):S311.

37. Kielland, J. 1937. Individual activity coefficients of ions in aqueous solutions. J. Am. Chem. Soc. 59:1675-1678.

38. Swallow, C. J., S. Grinstein, and O. D. Rothstein. 1990. A vacuolar type ATPase regulates cytoplasmic $\mathrm{pH}$ in murine macrophages. J. Biol. Chem. 265:7645-7654.

39. Kurtz, I. 1987. Apical $\mathrm{Na}^{+} / \mathrm{H}^{+}$antiporter and glycolysis-dependent $\mathrm{H}^{+}$ATPase regular intracellular $\mathrm{pH}$ in the rabbit $\mathrm{S}_{3}$ proximal tubule. J. Clin. Invest. $80: 928-935$

40. Bradbury, N. A., and R. J. Bridges. 1994. Role of membrane trafficking in plasma membrane solute transport. Am. J. Physiol. 267:C1-C24.

41. Arkett, S. A., S. J. Dixon, and S. M. Sims. 1992. Substrate influences rat osteoclast morphology and expression of potassium conductances. J. Physiol. 458:633-653.

42. Sundquist, K., P. Lakkakorpi, B. Wallmark, and K. Väänänen. 1990. Inhibition of osteoclast proton transport by bafilomycin Al abolishes bone resorption. Biochem. Biophys. Res. Commun. 168:309-313.

43. Zeuzem, S., P. Feick, P. Zimmerman, W. Haase, R. A. Kahn, and I. Schulz. 1992. Intravesicular acidification correlates with binding of ADP-ribosylation factor to microsomal membranes. Proc. Natl. Acad. Sci. USA. 89:6619-6623. 44. Zeuzem, S., P. Zimmermannn, and I. Schulz. 1992. Association of 19and a 21-kDa GTP-binding protein to pancreatic microsomal vesicles is regulated by the intravesicular $\mathrm{pH}$ established by a vacuolar-type $\mathrm{H}^{+}$-ATPase. J. Membrane Biol. 125:231-241.

45. Palokangas, H., K. Metsikko, and K. Väänänen. 1994. Active vacuolar $\mathrm{H}^{+}$-ATpase is required for both endocytic and exocytic processes during viral infection of BHK-21 cells. J. Biol. Chem. 269:17577-17585.

46. Lukacs, G. L., A. Kapus, A. Nanda, R. Romanek, and S. Grinstein. 1993 Proton conductance of the plasma membrane: properties, regulation and functional role. Am. J. Physiol. 265:C3-C14.

47. Laitala, T., and H. K. Väänäen. 1994. Inhibition of bone resorption in vitro by antisense RNA and DNA molecules targeted against carbonic anhydrase II or two subunits of vacuolar $\mathrm{H}^{+}$-ATPase. J. Clin. Invest. 93:2311-2318.

48. Nordstrom, T., O. D. Rotstein, R. Romanek, S. Asotra, J. N. M. Heersche

M. F. Manolson, G. F. Brisseau, and S. Grinstein. 1995. Regulation of cytoplasmic pH in osteoclasts. J. Biol. Chem. 270:2203-2212.

49. Nakamura, I., N. Takahashi, T. Sasaki, Y. Fukui, N. Udagawa, H. Murakami, S. Tanaka, T. Kurokawa, and T. Suda. 1994. Wortmannin, an inhibitor of phosphatidylinositol 3-kinase blocks the formation of ruffled border membrane in osteoclast. J. Bone Miner. Res. 9(S1):S155.

50. Zhang, D., H. Murakami, N. Udagawa, I. Nakamura, S. Saito, Y. Shibasaki, N. Morii, S. Narumiya, N. Takahashi, and T. Suda. 1994. The small GTP-binding protein rho is involved in osteoclastic bone resorption by regulating podosome formation. J. Bone Miner. Res. 9(S1):S131. 